\title{
Introduction
}

\section{Austerity, Labour and Social Mobilizations: Rebuilding Trade Union and Working Class Politics}

\author{
CARLO FANELLI \\ Department of Politics \& Public Administration at Ryerson University \\ PETER BROGAN \\ Department of Geography at York University
}

Since 2008, austerity has dominated the public policy agenda across the political spectrum. Across North America and Europe this has meant an emboldened radicalism from conservatives as new pressures to privatize public services, in particular health care, pensions and public education, coalesce with efforts to implement so-called right-to-work laws and the removal of public sector collective bargaining rights. Furthermore, the right to demonstrate and protest - the most basic of fundamental freedoms - has been severely constrained amidst hardening disciplinary and repressive state apparatuses. This remaking of social relations and institutional structures, however, has not been solely a matter of conservative class war, but has also been deepened and extended by liberals and social democrats with the backing of ruling class circles. Work for welfare initiatives, the weakening of employment standards legislation, attacks against social assistance minimums and the erosion of progressive taxation, once deemed central to the "new deal," are now deemed extravagant entitlements allegedly unaffordable in a new age of global capitalism (Pantich \& Gindin, 2012).

The public sector, especially unionized workers, have become a prime target of restructuring as capital and the state seek to create new spaces for accumulation. These new pressures have traversed scales of public administration, ushering in what can otherwise be termed an era of "permanent austerity.” Despite capitalist class and state militancy, however, 
unions and progressive social movements have been unable to stop, let alone reverse, decades of combined and uneven retrenchment (Fanelli, 2013; Lichtenstein, 2012; Panitch \& Swartz, 2003; Ross \& Savage, 2013). The effects of these policies, of course, have not been class neutral. Rather, those who caused the crisis in the first place - the capitalist class and states which enable them-continue to shift the costs of the crisis onto working class communities. The politics of austerity exacerbate racialized and gendered oppressions in the form of wage and benefit concessions, reductions to social services and increases in unpaid labour, further reinforcing ethno-racial and gendered hierarchies. Oftentimes for labour, successes have now been reduced to limiting the extent of concessions in their various forms, while social movements generally struggle with finding new ways of mobilizing against the upsurge in authoritarian populism.

This special issue of Studies in Social Justice reveals that regardless of the political party or coalition in power there has been a common tendency to further discipline workers to the imperatives of capital amidst a hardening of neoliberalism. With evermore authoritarianism and coercion, the state has come to lead in narrowing the field of free collective bargaining, suspending trade union rights and implementing an aggressive program of dispossession. Without the collective capacities to successfully challenge these measures, unions have reached an impasse; unable to translate militancy (where it is enacted) into an alternative ideological perspective and political and economic program, they desperately continue to hang onto previous gains that look increasingly insecure and fragile in an age of austerity. How, then, might workers in North America and Europe rebuild trade union capacities and working class politics? What lessons can be learned from municipal workers' struggles? What new forms of trade union organizing have been effective in contesting the austerity agenda? How have social movements and progressive forces adapted and responded to these new conditions?

The articles which follow begin to address precisely these questions. In a thorough reappraisal of US labour and social movement literature, Keith Mann analyzes the current state of international protest and trade union confrontation. He argues that a closer look at labour mobilizations over the last five years reveals a new form of emergent activism. From the Arab Spring to anti-austerity protests in Greece and Spain, the Occupy Wall Street Movement and labour struggles in Wisconsin and Chicago, Mann challenges common assumptions about so-called old and new social movements. He suggests that a new labour movement is emerging that shares many common features with new social movements, such as a universalistic emphasis on deeper democracy, social justice, an end to racial and gender oppressions, and good jobs for all. In this sense, the old demarcation between labour on the one hand and social movements on the other is increasingly blurred as the two coalesce around common struggles.

Next, Peter Brogan analyzes the Chicago Teachers Union (CTU) transformation from business to radical unionism. He shows how the CTU effectively challenged austerity measures by building a broad-based, rank- 
and-file-led activist union that places social justice at the forefront of their demands. Brogan discusses the political and economic pressures that preceded the 2012 round of negotiations between the Chicago Board of Education and the teachers' union, and explores the uniqueness of the 2012 strike and its aftermath, with particular attention on its implications for broader social justice struggles across Chicago and beyond. He shows how an amalgam of socialist and progressive activists was able to build unity across the union, effectively challenge the entrenched leadership, and build an empowering working class unionism by developing a long-term strategy and vision for change. In a similar vein, Carlo Fanelli explores attacks against trade union rights and freedoms for municipal workers in the city of Toronto. Fanelli contends that, like in the Chicago case, the municipal state propagated a false trade-off between wage restraint on the one hand and the protection of public services on the other, using it as a divisive wedge strategy to separate the users from the producers of public services.

As part of this strategy, this meant structurally shifting the burden of recession onto workers and the users of public services by further marketizing and commodifying the public sphere. Fanelli explores the concession-filled 2012 round of collective bargaining between the Canadian Union of Public Employees (CUPE) Locals 79/416 and the city of Toronto. He makes the case for an alternative political strategy for municipal public sector unions while stressing the importance of a radicalized labour movement rooted in demands for workplace democracy and social justice. The experiences of the CTU and CUPE Locals 79 and 416 paint a vivid picture of resurgent neoliberalism in the wake of the Great Recession. While each case study has its own specificity, together they provide fruitful terrain for developing an understanding of how long-term neoliberal policies are expanded and intensified in moments of crisis, while at the same time illustrating how global cities continue to be critical spaces of both neoliberal policy experimentation and contestation.

The concluding article by Jiři Navrátil, explores the evolution of the Czech social justice movement over the last decade. He discusses how progressive movements have evolved over time and what transformative factors have impacted their potency. Navrátil shows how the scale and focus of social mobilization and activism have vacillated over time, traversing transnational, domestic and localized scales. Examining the splits amongst social justice groups, he discusses how an emphasis on anti-war mobilizations, antiglobalization protests, police repression, demands for deeper democracy, and socio-economic dislocations has shifted over time. Navrátil concludes by discussing the reasons for the recent domestication of Czech social justice activism, with a particular emphasis on recent mobilizations against hardRight populist governments pushing a program of austerity and privatization. While each of the unions and social justice movements involved in these struggles have had very different historical trajectories, relationships with the state and political cultures, collectively Mann, Brogan, Fanelli and Navrátil illustrate the variety of forms of resistance and mixed successes of those struggling for democracy and social justice in the twenty-first century. 


\section{Resisting Austerity: The Case for a Radical Politics}

If trade unions and working class communities are to resist austerity, rebuilding the capacities of organized labour to fight back against concessionary demands must seek to build community-labour coalitions from the bottom up (Brogan, 2013; Tattersall, 2010). As long argued by scholar-activists like Sam Gindin (1995; 2006; 2012), Kim Moody (1988; 2007), Bill Fletcher Jr. and Fernando Gapasin (2009), in order for unions to live up to their potential as transformative workers' organizations, they will need to be reinvented. As part of this strategy of reinvention, a revived emphasis on working class politics must seek to transcend what are often insulated labour and activist subcultures. Considering the weak state of anti-capitalist/progressive forces and organized labour in North America and Europe and their inability to translate support for their political positions into broader political influence, new political organizations and sustained mobilizations that challenge the rule of capital are gravely needed. If unions are to reappear as a movement and not simply hang on as a relic of the past, they will need to move beyond the limited defence of their own members' interests and fight for the interests of the working class as a whole. As the articles collected here suggest, doing so requires having feet both inside and outside the trade union movementthat is to say, rooted in an organizational form explicitly intent on building a broader working class movement across the many cleavages among workers and grounded in a critical analysis of (neoliberal) capitalism. In light of historical and contemporary attacks against free collective bargaining, it is becoming increasingly clear that unions and oppressed persons generally can no longer, if they ever could, put their faith in the courts, laws or governments to enforce the postwar class compromise. This postwar "consensus" has been thoroughly eroded in the face of trade union and social justice activists' inability to adequately counteract cumulative decades of concerted attacks.

Despite four decades of neoliberalism and the intensified attacks following the Great Recession, there has yet to be a commensurate rejuvenation of socialist- and anti-capitalist- inspired mobilizations. Examining the reasons for these failings is important since the shapes taken (or not taken) by struggles over austerity and social justice will determine whether neoliberalism continues uninterrupted or whether something new and historically unique can capture the public's imagination. Considering what the working class is facing collectively, organizing solely around specific issues, workplaces and particular constituencies cannot add up to the kind of strength, organization and structure that is needed to bring about wide-ranging change. Although labour unions often remain the largest, most organized, resourced and stable institutions fighting against the rule of capital, they cannot themselves beat back the consolidated attacks by the state and capital. While trade unions must be a central part of any radical political renewal, their rebirth is equally dependent upon a broader revitalization of the Left outside of organized labour and working class politics as a whole - what Marx identified as a social and political formation united in difference. The course of neoliberalism has thoroughly eroded what vestiges remain of trade union militancy, while 
social movements generally remain isolated in small-scale and resource-poor coalitions. Given the ongoing onslaught against public services, private and public sector unions and progressive movements, trade unionists and social justice activists must come to the bitter realization that the existing ways of doing things are not working. This, in our view, is the only realistic starting point from which to move forward.

The inability of both organized labour and activists to confront this impasse belies the need for a new kind of radical, anti-capitalist political project suited to the current historical and social conjuncture, one that interrogates both its own historical failures as well as the transformations in the political, economic, socio-spatial and cultural changes under which we are struggling today. The challenge before trade union and social justice activists is to move left of social democracy or risk increasingly becoming an impediment to rather than an instrument of a renewed working class politics. In other words, labour and social justice activists must lead left if austerity is to be challenged. The failure to do so may regrettably amount to an historic class defeat. Despite the setbacks to trade unionists and social justice activists over the period of neoliberalism, it is necessary to learn victory from defeats. Revitalizing the theoretical and political promise of a radical working class politics remains a crucial step in resisting austerity and potentially realizing a better world that gets to the root of the problem - capitalism.

\section{References}

Brogan, P. (2013). In struggle together: Reflections on labor-community alliances in the fight for education justice. Progressive Planning Magazine, 197, 40-44.

Fanelli, C. (2013). Fragile future: The attack against public services and public sector unions in an era of austerity. Unpublished doctoral dissertation. Carleton University, Ottawa.

Fletcher, B. Jr. \& Gapasin, F. (2007). Solidarity divided: The crisis in organized labor and a new path toward social justice. Berkeley: UC Press.

Gindin, S. (1995). The Canadian Auto Workers: The birth and transformation of a union. Toronto: Lorimer.

Gindin, S. (2012). Rethinking unions, registering socialism. In L. Panitch, G. Albo, \& V. Chibber, (Eds.), The question of strategy, Socialist Register 2013 (pp. 26-51). London: Merlin Press.

Gindin, S. \& Stanford, J. (2006). Canadian labour and the political economy of transformation. In V. Shalla, (Ed.), Working in a global era: Critical perspectives (pp. 379-394). Toronto: Canadian Scholars Press Index.

Jordus-Lier, D. (2012). Public sector labour geographies and the contradictions of state employment. Geography Compass 6/7, 423-438.

Lichtenstein, N. (2012). State of the Union: A century of American labor. Princeton: Princeton University Press.

Moody, K. (1988). An injury to all: The decline of american unionism. New York: Verso.

Moody, K. (2008). US labor in trouble and transition. The failure of reform from above, the promise of revival from below. London: Verso

Panitch, L., \& Swartz, D. (2003). From consent to coercion: The assault on trade union freedoms. Aurora, ON: Garamond Press.

Panitch, L., \& Gindin, S. (2012). The making of global capitalism: The political economy of American empire. London: Verso.

Ross, S., \& Savage, L. (Eds.). (2013). Public sector unions in the age of austerity. Halifax: Fernwood.

Tattersall, A. (2010). Power in coalition: Strategies for strong unions and social change. Ithaca: Cornell University Press. 